\title{
The Effect of Work Environment and Work Stress on Employee Performance at PT Aneka Gas Industri Tbk
}

\author{
Endang Haryati ${ }^{1}$, Agung Suharyanto ${ }^{2}$, Babby Hasmayni ${ }^{3}$, Farida Hanum Siregar ${ }^{4}$ \\ \{endangharyati@staff.uma.ac.id ${ }^{1}$, agungsuharyanto@staff.uma.ac.id ${ }^{2}$, babby@staff.uma.ac.id ${ }^{3}$, \\ farida@staff.uma.ac.id $\left.{ }^{4}\right\}$ \\ 1,3,4 Department of Psychology Universitas Medan Area, Indonesia \\ ${ }^{2}$ Department of Public Administration Universitas Medan Area, Indonesia
}

\begin{abstract}
This research was conducted to determine how much influence the work environment and work stress on the performance of employees at PT Aneka Gas Industry Tbk. This study uses a quantitative approach. The samples taken in this study were employees at PT Aneka Gas Industry Tbk, which amounted to 35 people (respondents). Data collection is done using a questionnaire while the data analysis uses the SPSS 25 application. Data collected using questionnaires have been tested for validity and reliability. The results of this study indicate that: (1) The work environment has an effect on the performance of employees of PT Aneka Gas Industry Tbk, evidenced by the results of regression calculations obtained beta values $(\beta)$ of 0.496 and on independent variables (X1) (independent) namely Work Environment (3,935> 1.6923) then H0 is rejected and $\mathrm{Ha}$ is accepted, meaning that there is an influence between the Work Environment (independent). (2) Job stress has a positive but not significant effect on the performance of employees of PT Aneka Gas Industry Tbk. This is evidenced by the results of regression calculations obtained beta value $(\beta)$ of 0.013 and on the independent variable (X2) (independent) namely Job Stress (-, $0171<1.6923)$, then H0 is accepted and $\mathrm{Ha}$ is rejected then there is no effect of Job Stress on Employee Performance. (3) Effect of Work Environment and Job Stress on Employee Performance at PT Aneka Gas Industry Tbk. the results of calculations using SPSS 25 computerization can be seen that the value of Adjusted R Square generated is equal to $0.284(28.4 \%)$ then it can be interpreted as a contribution to the variable work environment and work stress on performance is $28.4 \%$ while $71.6 \%$ is influenced by other variables.
\end{abstract}

Keywords: Environment, Stress, Performance.

\section{Introduction}

In the current era of globalization, a company is required to be able to compete and improve the quality of the company by maximizing employee performance. To improve the quality of employee performance, companies must pay attention to the development, comfort, and safety of their employees. This means that companies must be able to analyze the factors that can affect employee performance. One of the factors that influence employee performance is the work environment. The work environment is an area, place and everything from equipment to equipment used and supports and facilitates work activities within a company that affects workers in carrying out their duties. The condition of the work environment is said to be good or appropriate if humans can carry out activities optimally, healthy, safe, and 
comfortable. If a good working environment is not achieved, work stress will occur on the employee.

Job stress is a condition created by physical and psychological imbalances that affect the emotions and conditions of an employee, so they often become angry, sensitive, unable to calm down, and difficult to work together. There are two factors causing work stress, namely work environment factors and personal factors. According to Anorogo and Widiyanti in the journal Wicaksono [1] "the work environment is everything that is around the employee and that can affect him in carrying out the tasks that are charged".

The work environment is very influential in the implementation of task completion. Marwansyah [2], "Internal environment (work) are general factors or conditions within an organization, which affect the management of the organization". From the above statement, it can be concluded that the work environment is everything that exists around the employee both conditions or atmosphere and also the equipment used that can influence employees in carrying out the tasks given. According to Nitisemito in the journal Wicaksono [1] states that the work environment is measured through indicators as follows: (1) working atmosphere, that every employee always wants a pleasant work atmosphere, a comfortable working atmosphere that includes clear light, quiet and quiet sounds, safety at work.

The amount of compensation provided by the company will not affect optimally if the work atmosphere is less conducive. This is consistent with Soedarmayanti's opinion in the journal Wicaksono [1] "That lighting, noise level (quietness) and room temperature as indicators of the work environment positively affect employee performance". This is also under Rahmawati's opinion [3], a comfortable work environment is not only influenced by lighting and sound, but the next factor is also air or air circulation and safety. Rooms that are too hot or too cold can affect employees, (2) relationships with colleagues are harmonious and without any intrigue between colleagues. One of the factors that can influence employees to remain in an organization is a harmonious relationship between co-workers. A harmonious and friendly colleague relationship is one of the factors that can affect employee performance and (3) availability of work facilities used to support complete/up-to-date work. The availability of complete work facilities, although not new is one of the supporting processes of smooth work.

Fahmi [4] "Stress is a condition that presses one's self and soul beyond the limits of his ability so that if left unchecked without a solution then this will have an impact on his health". Stress does not arise just like that, but the causes of stress arise are generally followed by factors that affect a person's psyche and events that occur outside of his ability so that the condition has suppressed his soul. According to Stephen P. Robbins in Sutrisno [5], stress is a dynamic condition in which an individual is confronted with an opportunity, constraint or demand that is associated with what he wants and is ultimately considered as uncertain and important. According to T. Hani in the journal Sutrisno [5], "Stress is a condition of tension that affects emotions, thought processes and one's condition".

According to Cooper in the Primary journal [6] states that there are four sources of work stress, namely as follows (1) poor work conditions have the potential to cause employees to fall ill easily, if the room is uncomfortable, hot, inadequate air circulation, the workspace is too dense, the work environment is less clean and noisy, of course it has a major effect on employee work comfort, (2) overload can be distinguished quantitatively and qualitatively. It is said to be quantitatively overloaded if the number of targeted jobs exceeds the capacity of the employee. As a result, these employees are easily tired and are at a high voltage. Qualitatively overloaded when the job is very complex and difficult so that it seizes the ability of employees, (3) derivational stress, namely work conditions are no longer challenging, or no 
longer attractive to employees. Usually complaints that arise are boredom, dissatisfaction, or the work lacks social elements (lack of social communication), (4) high-risk or hazardous work, such as work in offshore oil mining, the army, and so on, (5) a dual role is the role of an employee of more than one task or role in the company so as to cause disruption to the employee's performance, and (6) personal problems are problems that are experienced and faced by humans as individuals (personal), and individuals who experience these problems do not want the problem to be known by many people and try to cover it up because he will feel ashamed if the problem is known by others.

Handoko [7] "Performance is the result obtained by an organization both the organization is profit-oriented and non-profit oriented which is produced over some time". Indrasari [8], "Performance is a set of results achieved and refers to actions". According to Stoner [8], "The fact that performance is a function of motivation, skills, and role perception". Indra Bastian [7], said that performance is a picture of the level of achievement of the implementation of an activity/program/ policy in realizing the goals, objectives, mission, and vision of the organization as outlined in the formulation of the strategic planning (strategic planning) of an organization.

According to Riordan in Christi et al in the journal Wicaksono [1], indicators of performance are (1) job description is a written statement describing the responsibilities that must be carried out from a particular job, (2) job quantity, i.e. if a person can complete his work within a predetermined time period, (3) timeliness, is a certain type of work requires the presence of employees in doing it in accordance with the specified time, and (4) quality of work, means that every employee is able to recognize and solve relevant problems and have a positive work attitude at work.

\section{Research methods}

To obtain or collect data and information that leads to truth and to the right target, the data collection techniques used for this research are (1) field research including (a) observation, the method used for data collection by direct observation at PT Aneka Gas Industry Tbk, and (b) questionnaire, the method used for data collection by distributing lists, and (2) library research. Which collects supporting information about work stress, work environment and employee performance through scientific books. Written questions to related parties who can provide information to obtain complete data and information.

Table 1. Rating Likert Scale

\begin{tabular}{cc}
\hline the answer & score \\
\hline Agree (SS) & 4 \\
Agree (S) & 3 \\
Disagree (TS) & 2 \\
Disagree (STS) & 1 \\
\hline
\end{tabular}

Operational variables are the breakdown of research variables into sub-variables and indicators. The research indicators on work stress are as follows in Table 2 below. 
Table 2. Operational definition

\begin{tabular}{|c|c|c|c|}
\hline Variable & Definition & Indicator & Measurement \\
\hline $\begin{array}{l}\text { Work Environment } \\
\text { (X1) }\end{array}$ & $\begin{array}{l}\text { Work is anything that's } \\
\text { around the employee } \\
\text { and that can affect him } \\
\text { in carrying out the tasks } \\
\text { that are charged. }\end{array}$ & $\begin{array}{c}\text { Work atmosphere } \\
\text { Relationships with } \\
\text { officemate } \\
\text { Work facilities }\end{array}$ & $\begin{array}{l}\text { Likert scale with } \\
\text { score weights are: } \\
=\text { Disagree } \\
=\text { Disagree } \\
=\text { Agree } \\
=\text { Agree }\end{array}$ \\
\hline Variable & Definition & Indicator & Measurement \\
\hline Stress (X2) & $\begin{array}{l}\text { Job stress is a process } \\
\text { that causes people to } \\
\text { feel sick, uncomfortable } \\
\text { or tense due to work, } \\
\text { workplace or certain } \\
\text { work situations }\end{array}$ & $\begin{array}{c}\text { Workload } \\
\text { Pressure or time } \\
\text { pressure } \\
\text { Frustrated } \\
\text { Double role Personal } \\
\text { problems }\end{array}$ & $\begin{array}{c}\text { Likert scale with } \\
\text { score weights are: } \\
\text { 1 = Disagree } \\
2=\text { Disagree } \\
3=\text { Agree } \\
4=\text { Agree }\end{array}$ \\
\hline Variable & Definition & Indicator & Measurement \\
\hline $\begin{array}{c}\text { Employee } \\
\text { performance }(\mathrm{Y})\end{array}$ & $\begin{array}{l}\text { Performance is the } \\
\text { result obtained by an } \\
\text { organization both the } \\
\text { organization is profit- } \\
\text { oriented and nonprofit } \\
\text { oriented which is } \\
\text { produced over some } \\
\text { time }\end{array}$ & $\begin{array}{l}\text { Job description } \\
\text { Work quantity } \\
\text { Punctuality } \\
\text { Quality of work }\end{array}$ & $\begin{array}{c}\text { Likert scale with } \\
\text { score weights are: } \\
\text { 1 = Disagree } \\
2 \text { = Disagree } \\
3=\text { Agree } \\
4=\text { Agree }\end{array}$ \\
\hline
\end{tabular}

The data analysis method used in this study to measure the results of the questionnaire using a Likert scale, Likert scale is a scale used to measure attitudes, opinions, and perceptions of a person or group of people about social events or symptoms.

(1) T-test

The T-test is used to test the significance of the effect between the variables $\mathrm{X}$ and $\mathrm{Y}$. The $\mathrm{t}$ calculation formula is as follows:

$$
\mathrm{t}=(\mathrm{r} \sqrt{ }(\mathrm{n}-2)) / \sqrt{ }\left(1-\mathrm{r}^{\wedge}\right.
$$

As for: $\mathrm{t}$-count $<\mathrm{t}$-table $=$ Hypothesis rejected $(\mathrm{H} 0)$

$\mathrm{t}$-count $>\mathrm{t}$-table $=$ Hypothesis accepted $(\mathrm{H} 0)$

\section{(2) Determination}

The determination test is used to see the degree of relationship between the independent variable and the dependent variable partially. If the correlation (R) approaches 1 then the degree of relationship is very strong whereas if the coefficient $(\mathrm{R})$ approaches 0 then the degree of relationship can be said to be weak.

(3) Multiple Linear Regression Analysis

Multiple linear regression analysis is a statistical technique used to find a regression equation that is useful for predicting the value of the dependent variable based on the values of the independent variables and look for possible errors and analyze the relationship between one dependent variable with two or more independent variables both simultaneously and 
partially. Multiple linear regression analysis is used to test whether the independent variable influences the dependent variable simultaneously or partially. The multiple linear regression equation, namely:

$$
\mathrm{Y}=\mathrm{a}+\mathrm{b} 1 \mathrm{x} 1+\mathrm{b} 2 \mathrm{x} 2
$$

Which:

$\begin{array}{ll}\text { Y } & \text { : Dependent Variable } \\ \text { A } & \text { : Constant } \\ \text { b1 } & \text { : First Regression Coefficient } \\ \text { b2 } & \text { : Second Regression Coefficient } \\ \text { X1 } & \text { : First Independent Variable } \\ \text { X2 } & \text { : Second Independent Variable }\end{array}$

The following are guidelines for providing interpretation and analysis for correlation coefficients:

$$
\begin{aligned}
& 0.00-0.199=\text { very low } \\
& 0,20-0,3999=\text { low } \\
& 0.40-0.5999=\text { moderate } \\
& 0.60-0.799=\text { strong } \\
& 0.80-1,000=\text { very strong }
\end{aligned}
$$

\section{Result and discussion}

Table 3. Multiple Correlation Analysis (R)

\begin{tabular}{cccccccccc}
\hline Model & $\mathrm{R}$ & $\mathrm{R}$ & Adjusted & Std. \\
Square & R Square & $\begin{array}{c}\text { Stror of } \\
\text { the } \\
\text { Estimate }\end{array}$ & $\begin{array}{c}\text { Square } \\
\text { Change }\end{array}$ & $\begin{array}{c}\mathrm{F} \\
\text { Change }\end{array}$ & df1 & df2 & $\begin{array}{c}\text { Sig. F } \\
\text { Change }\end{array}$ \\
\hline 1 & $.571 \mathrm{a}$ & .326 & .284 & 1.823 & .326 & 7.743 & 2 & 32 & .002 \\
\hline
\end{tabular}

The following are guidelines for providing interpretation and analysis for correlation coefficients:
a. $0.00-0.199=$ very low
b. $0,20-0,3999=$ low
c. $0.40-0.5999=$ moderate
d. $0.60-0.799=$ strong
e. $0.80-1,000=$ very strong

Table 3. T Test Result 


\begin{tabular}{ccccc}
\hline B & Std eror & Beta & T & Sig \\
\hline 7.250 & 4.538 & & 1.582 & .124 \\
.496 & .126 & 572 & 3.935 & .000 \\
-.013 & .077 & -.025 & -.171 & .866 \\
\hline
\end{tabular}

The t-test was carried out using the following criteria: (1) t-count <ttable, then $\mathrm{HO}$ is accepted and $\mathrm{Ha}$ is rejected then there is no influence of work environment and work stress on employee performance, and (2) tcount $>\mathrm{t}$-table, then $\mathrm{H} 0$ is rejected and $\mathrm{Ha}$ is accepted then there is an influence of work environment and work stress on employee performance.

Based on Table $4, t_{\text {count }}>t_{\text {-table. }}$ T-table values can be seen at the distribution $t$ percentage point. So, the independent variable (X1) (independent), namely the Work Environment (3.935> 1.6923), H0 is rejected and $\mathrm{Ha}$ is accepted, meaning that there is a persistently influence between Work Environment (independent) on Employee Performance (dependent). While the independent variable (X2) (independent) is Work Stress $(-0.171<1.6923)$, then H0 is accepted and Ha is rejected, so there is no effect of Work Stress on Employee Performance.

\begin{tabular}{|c|c|c|c|c|c|c|c|c|c|}
\hline Model & $\mathrm{R}$ & $\begin{array}{c}\mathrm{R} \\
\text { Square }\end{array}$ & $\begin{array}{l}\text { Adjusted } \\
\text { R Square }\end{array}$ & $\begin{array}{c}\text { Std. An } \\
\text { error of } \\
\text { the } \\
\text { Estimate }\end{array}$ & $\begin{array}{c}\text { R } \\
\text { Square } \\
\text { Change }\end{array}$ & $\begin{array}{c}\mathrm{F} \\
\text { Change }\end{array}$ & df1 & df2 & $\begin{array}{l}\text { Sig. F } \\
\text { Change }\end{array}$ \\
\hline 1 & $.571 \mathrm{a}$ & .326 & .284 & 1.823 & .326 & 7.743 & 2 & 32 & .002 \\
\hline
\end{tabular}

Based on Table 5 above, calculations using SPSS 25 can be seen that the value of Adjusted R Square that has been generated is equal to 0.284 (28.4\%), it can be concluded that the contribution simultaneously of the work environment and work stress variables to performance is $28.4 \%$ while the remaining $71.6 \%$ is influenced by other variables.

The results obtained by the author in this study through the distribution of questionnaires to 35 respondents, namely employees at PT Aneka Gas Industry Tbk. This study aims to determine the effect of the work environment and work stress on employee performance at PT Aneka Gas Industry Tbk. This study uses 12 indicators of 3 variables, namely the number of statements 26 on the work environment variable (X1), work stress variable (X2) and employee performance variable (Y) as a benchmark in making the questionnaire. Based on the research conducted, the writer will discuss it.

The results of this study indicate that the work environment variable influences the performance of the employees of PT Aneka Gas Industry Tbk. This is evidenced by the results of the regression calculations obtained by the value of beta $(\beta)$ of 0.496 and the independent variable (X1) (independent) namely the Work Environment (3.935> 1.6923) then H0 is rejected and $\mathrm{Ha}$ is accepted meaning that there is a partial effect between the Work Environment (independent) on Employee Performance (dependent), then the first hypothesis is accepted. Hypothesis testing results have shown that the work environment can affect employee performance, meaning that the work environment in the company is more conducive such as safe, comfortable and pleasant environmental conditions so that employees can carry out work activities with high spirits and positive thoughts so that will affect the achievement of more optimal performance.

The results showed that the work stress variable did not affect the performance of the employees of PT Aneka Gas Industry Tbk. This can be proven by the results of the regression calculation so that a beta value $(\beta)$ of 0.013 is obtained and the independent variable (X2) (independent) is Work Stress $(-, 0171<1.6923)$, then H0 is accepted and Ha is rejected then 
there is no effect Job Stress on Employee Performance. This means that the results of research that have been done cannot be used in general that work stress affects the performance of employees at agencies or companies other than PT Aneka Gas Industry Tbk. This shows that work stress can create a competitive advantage for the company. However, if the work stress experienced by the employee is too high, it will make the employee's performance disturbed.

The results showed that the work environment and work stress variables together had a positive effect on employee performance. This is evidenced by the results of the regression test statistics obtained by the work environment with the results of the regression calculation obtained a beta value $(\beta)$ of 0.496 and the independent variable (X1) (independent) namely the Work Environment (3.935> 1.6923) then $\mathrm{HO}$ is rejected and $\mathrm{Ha}$ is accepted meaning partially there is an influence between the Work Environment (independent) on Employee Performance (dependent), while the results of the regression calculation obtained a beta value $(\beta)$ of 0.013 and the independent variable (X2) (independent) namely Work Stress (-, $0171<1.6923)$, then $\mathrm{H} 0$ is accepted and $\mathrm{Ha}$ is rejected, so there is no influence of work stress on employee performance, so the hypothesis can be stated partially accepted, because only the work environment has a positive and significant effect on employee performance.

While work stress has a positive but not significant effect on employee performance. The results of calculations using computerized SPSS 25 can be seen that the value of Adjusted R Square produced is equal to $0.284(28.4 \%)$ then it can be interpreted that the contribution or contribution simultaneously work environment variables and work stress on performance is $28.4 \%$ while $71.6 \%$ is influenced by other variables.

\section{Conclusion}

The work environment has an influence on the performance of the employees of PT Aneka Gas Industry Tbk, as evidenced by the results of the regression calculation obtained a beta value $(\beta)$ of 0.496 and the independent variable (X1) (independent) namely the Work Environment (3.935> 1.6923) then H0 is rejected and Ha accepted means that there is a partial influence between the Work Environment (independent) on employee performance.

Job stress does not influence the performance of the employees of PT Aneka Gas Industry Tbk. This is evidenced by the results of the regression calculation obtained a beta value $(\beta)$ of 0.013 and the independent variable (X2) (independent) namely Work Stress $(-, 0171<1.6923)$, then $\mathrm{HO}$ is accepted and $\mathrm{Ha}$ is rejected then there is no effect of Job Stress on Employee Performance.

The Effect of Work Environment and Work Stress on Employee Performance at PT Aneka Gas Industry Tbk. the results of calculations using computerized SPSS 25 can be seen that the resulting Adjusted R Square value That is equal to 0.284 (28.4\%), it can mean the contribution or contribution simultaneously of work environment variables and work stress on performance is $28.4 \%$ while $71.6 \%$ is influenced by other variables. Based on research that has been done, the writer wants to give some advice, namely (1) the Work Environment has a positive influence on Employee Performance at PT Aneka Gas Industry Tbk. The existence of mosquito disturbances, strong odors from gas, light in the room, air ventilation and work facilities in the work environment that can interfere with an employee. performance. For this reason, the company should hold fogging periodically to overcome mosquito disorders and provide appropriate masks to overcome the pungent odor and maintain the cleanliness of the work environment by clearing disturbing shrubs in the work environment and equipping 
facilities for employees to become comfortable in working, (2) using other methods in researching work environment, work stress with employee performance. Other methods that can be used include interview methods, mix methods (combining interview and questionnaire methods). Future studies are expected to add and examine other variables such as discipline and compensation for employee performance.

\section{References}

[1] A. P. Wicaksono, "Pengaruh Lingkungan Kerja Dan Stres Kerja Terhadap Kinerja Karyawan Depot LPG Balongan PT Pertamina (Persero)," pp. 8-62, 2017.

[2] E. Sutrisno, "Pengaruh Stres Kerja Terhadap Kinerja Karyawan Di Madrasah Aliyah Negeri Demak," p. 3, 2014.

[3] Rahmawati, Manajemen Perkantoran, Yogyakarta: GRAHA ILMU, 2014.

[4] Prof. Dr. Sugiyono, Metode Penelitian, Bandung: ALFABETA, 2017.

[5] M. C. Pratama, "Pengaruh Lingkungan Kerja Dan Stres Kerja Terhadap Kinerja Pegawai Pada Badan Perencanaan Pembangunan Daerah Provinsi Lampung," pp. 17 24, 2016.

[6] Marwansyah, Manajemen Sumber Daya Manusia, Bandung: ALFABETA, 2016.

[7] D. M. Indrasari, S.T., M.M., Kepuasan Kerja dan Kinerja Karyawan, Yogyakarta: Indromedia Pustaka, 2017.

[8] D. T. H. Handoko, M.B.A., Manajemen, Yogyakarta: BPFE-YOGYAKARTA, 2017. 